

RESEARCH ARTICLE

\title{
ECONOMIC CONTRIBUTION OF FOREST RESOURCES TO SUSTAINABLE RURAL LIVELIHOODS IN BENCH MAJI ZONE, SOUTH WEST ETHIOPIA.
}

Mulatie Chanie and Tesfaye Yirsaw.

Department of Economics, Mizan Tepi University, Mizan Aman, Ethiopia.

\section{Manuscript Info}

Manuscript History

Received: 02 April 2018

Final Accepted: 04 May 2018

Published: June 2018

Keywords:-

Livelihood, Rural household, Forest Resource.

\begin{abstract}
This paper attempts to assess the contribution of forest resources to rural livelihoods in Bench Maji zone. To conduct this research both qualitative and quantitative information was collected from four woredas in Bench Maji zone through questionnaire, interview and focus group discussion from 200 rural households.

The finding of this study shows that the impacts of forest resources to rural livelihood are diverse in terms of livelihood means. Forest income is the second largest source of livelihood diversification next to agriculture. In addition, rural households in the study area use trade, rent of asset, and other source of livelihood strategies. The relationship between socio-economic characters of the respondents with forest resources shows distance, sex, family size, education level and access to agricultural land are significant determinant of forest resource use. As far as natural forest resources have an important contribution in the rural livelihood means, issues on forest resource and rural livelihood should not be ignored in policy decisions and other interventions. Consequently, steps to efficiently use forest resources should be undertaken by different bodies as one of the ways of improving rural households livelihood means.
\end{abstract}

Copy Right, IJAR, 2018,. All rights reserved.

\section{Introduction:-}

The history of human existence and civilizations is intertwined with forests and trees. Forests are crucial for the goods and services they provide, which people all over the world depend on. This forests and forest products have almost everywhere formed part of rural livelihood systems. Rural households filled gaps in the material and income flows from their on-farm resources by drawing on nearby areas of forest, woodland or scrubland. Access to forest or tree resources can also help rural households to diversify their livelihood base and reduce their exposure to risk. The united nation data shows that Over 1.6 billion people's livelihoods depend on forests and trade in forest products was estimated at $\$ 327$ billion in 2009 . In addition, forests are home to 300 million people around the world (UN, 2011).

In Sub-Saharan Africa, forest goods and services are extremely important for rural livelihoods, providing food, medicine, shelter, fuel and cash income. It is estimated that more than 15 million people in Sub-Saharan Africa earn their cash income from forest-related enterprises such as fuel wood and charcoal sales, small-scale saw-milling, commercial hunting and handicraft. In addition, between 200,000 and 300,000 people are directly employed in the commercial timber industry (Oksanen and Mersmann, 2003). For some countries, the forestry sector is an important 
foreign exchange earner. For example, between 1993 and 2002, the value of net exports of various wood-based products from countries in sub-Saharan Africa amounted to more than US\$2 billion (FAO, 2003).

Considering the agrarian base of the Ethiopian rural households' economy, the dominantly traditional farming methods and their dependence on natural resources, it can be expected that forest products have a significant role in rural livelihoods. Case studies (Mamo et al., 2007) show that rural households around forests in Ethiopia obtain diverse forest products and earn a considerable part of their income (39\%) from their use of forest resources. There are many aspects of this use including direct consumption of forest products and services (food, timber for construction, fuel wood, fodder for livestock, forest farming), collection of forest products for sale (hunting, NTFP collection etc) and the use of forest products for food security in times of seasonal shortages, drought and economic stress. In addition to the use of forest products for livelihood support and risk management, forests are potentially valuable to rural people as means of income generation and poverty reduction (Bekele, 2001).

The reliable estimate of forest cover based on thorough field inventory by the World Bank funded Woody Biomass Inventory and Strategic Planning Project (WBISPP), is 4.07 million hectares which is about $3.56 \%$ of the total area of the country (WBISPP, 2005). The estimate does not include woodlands and shrub lands categorized as nonforests - which cover an area of 29.2 million ha $(25.5 \%)$ and 26.4 million ha (23.1\%), respectively. Based on WBISPP's assessment, some 95\% of the existing forest is located in three regions - the Oromia, Southern Nations Nationalities and People, and Gambela regions which constitute $43 \%$ of the land area of the country.

A study by NTFP project of south-west Ethiopia center revealed that, the local communities in the south-west highlands of Ethiopia are highly dependent on the forest resources for their livelihoods. Over time they have developed various ways of using and managing these forests in order to meet their needs for a range of timber and non-timber forest products for household use and income generation. Furthermore, the study revealed that the problems hindering the utilization of forest resources in the study area including poor marketing and poor utilization technique which results little profit and increasing scarcity (NTFP, 2004).

Despite this important contribution of forests, most past information about the forest products and its uses has been narrowly specified and of limited relevance in understanding the broader role of such products in livelihoods. The economic role of forest resources in livelihood and poverty alleviation in developing countries is not yet wellknown. Only a few studies have been carried out on the economic effects of community forestry in developing countries (Dahal 2006). Consequently there is a lack of reliable community level economic data on the benefits and costs of community forest resources. So, this study attempted to provide more information on the role of forest resources to rural livelihoods in Bench Maji zone. It focused on the revenue generation of these forests resources compared to other main rural industries like agriculture, livestock, trade and other economic activities in Bench Maji zone.

\section{Statement of the Problem:-}

Rural households exist within a vulnerability context in which stresses and shocks affect their livelihood assets and options, over which they have very little control (Scoones, 1998). Since rural communities are not homogenous, different households experience different frequencies and types of vulnerability and responded differently. However, little is known on the role of forests in assisting rural households to cope with shocks and stresses especially in developing countries. Understanding people's use of provisioning services in responding to shocks and stresses is essential if the long-term goals of economic development and biodiversity conservation are to converge in regions with high poverty levels and biologically diverse ecosystems (Paumgarten and Shackleton, 2011).

The development discussion in Ethiopia is still dominated by the traditional view of farming, mainly crop and livestock production, as the mainstay of rural communities without due regard to the role of forest resources in people's livelihoods. Forest resources are valued only for the supply of household energy while other roles in the livelihoods of rural households are not fully appreciated. Income from forest resources are not properly valued and are usually lumped in a non-farm income category (SDPRP, 2002). The description of major farming systems in the country does not portray links with the natural resource component, particularly forest resources, despite the major role of forests in securing livelihood.

According to NTFP research and development project of south-west Ethiopia center report, many forest areas have been lost recently in Bench Maji zone. This was mainly due to the higher population pressure and expansion of the 
agricultural area, and also due to the expansion of commercial coffee plantations by the government and investors. In addition, the remaining natural forest is highly disturbed and is threatened by illegal timber and charcoal production, forest fires during honey harvesting especially in areas where there is undergrowth of bush grass (NTFP, 2004)

Within the zone variation in socio-economic status of different people exist which results a difference in dependency of the various socio economic characters on the forest resources. According to the results of the livelihood mapping of the zone, forest resources contribution takes the lion's share to the farmers' livelihood indicating that the zone largely rely on natural forest resources. However, it should be noted that, other livelihood sources of the zone need to be given due consideration in order to minimize the pressure on forest resources which will ultimately hamper the efforts on forest resources in a vicious circle manner (Ibid).

Lastly, the link between livelihood and forest resource degradation has been an influential but a contested issues. Besides, any effort to mitigate degradation of natural resources and alleviate poverty should be based on systematic analysis of the livelihoods of the rural poor and their interaction with the environment.

\section{Objective of the Study:-}

The general objective of the study was to define the role of forest resources to sustainable livelihood generation by comparing with other rural industries like agriculture, trade, wage income and others means of income in Bench Maji zone. In line with this main objective, the paper addressed the following specific objectives;

1. To assess the contribution of forest resources to livelihoods of local households.

2. To identify and describe the livelihood strategies of households

3. To understand how use and sale of forest resource services is differentiated by socio-economic character of the local people like wealth, gender, and age.

\section{Research Methodology:-}

\section{Sources and Method of Data Collection:-}

The paper relayed mainly on primary data. Primary data on forest resource uses and livelihood strategies of households are collected using focus group discussion, direct interview, and household questionnaire. Household questionnaires provides both quantitative and qualitative information on the links between forest resource uses and its impact on livelihoods, education, household composition, age, land and livestock holdings, sources of family income, existing livelihood pattern, degree of dependency on forest, employment wage and the like. In-depth interviews is carried out with Zone, Woreda and Kebelle level administrative bodies to get information on forest use and changes in use, and local institutions and structures that shape the use of forest resources. Focus group meeting with different populations (elders, men, women and youth) was held to obtaining a broader understanding of forest uses at the village level.

\section{Sampling Design:-}

Bench Maji zone has 10 Woredas with a total of 236 Kebelles. The total number of population in the zone according to the 2007 Census is 652,531 people and there are 157,598 households (CSA, 2008). For this study, the sampling frame (population) is the list of all households in the zone and the sampling unit in the household survey is the household, while the unit of observation is the household head. Households in this study are defined as "a group of people (normally family members) living under the same roof, and pooling resources."

The sampling technique (selection of target areas, groups and households) follows both purposive sampling as well as random sampling principles. First, four Woredas were chosen from the ten Woredas based on forest coverage purposively. Further, 10 Kebelle were chosen from these Woredas based on number of Kebelles randomly and ultimately a total of 200 sample households were selected from all sample Kebelle. For selection of sample households at each Kebelle, stratified sampling technique is employed that involves groupings of the study population into different wealth strata and selecting a random sample within each stratum. Wealth rank is used as the sampling strata. That is, households were stratified as poor and rich according to their wealth. This is because different wealth-rank groups show different levels of dependence on the forests due to their different livelihood activities and differential access to private resources. 
To classify the households in to different wealth group a household profile was prepared for each household and the criteria was livestock ownership, size and style of house, quality of assets owned, number of beehives, agricultural land holding and size of enset plantation. Within each wealth category from each Kebelle, a total of 200 individual households were selected randomly for detail survey.

\section{Method of Data Analysis:-}

The collected analyzed to extract meaningful information based on both descriptive and empirical data analysis techniques by using STATA software package. The descriptive analysis was supported with an empirical analysis using econometric model. To show the link between socio-economic characters of the respondents with forest resources, a multiple linear regression model was developed. This model shows forest income regressed as a function of other socio-economic characters (factors that affect the level of forest dependency) of the respondents.

\section{INCOMFF $=\beta_{0}+\beta_{1}$ Distance $+\beta_{2}$ Age $+\beta_{3}$ Education $+\beta_{4}$ Family $+\beta_{5}$ Sex $+\beta_{6}$ wealth $+\beta_{7}$ Occupation + U}

Where; INCOMFF = Income from forest resources in birr

Distance $=$ Distance between household home to forest area in kilometer

Age $=$ Age of household head

Education $=$ Level of education of the household head ( 1 if educated, 0 otherwise)

Family = Family size of the household

Sex $=$ sex of the household which takes a value 1 for male and 0 otherwise.

Wealth = wealth level of the household ( 1 if rich, 0 otherwise)

Occupation $=$ the type of job the household engaged $\left(D_{1}=1\right.$ if agriculture, 0 otherwise. $D_{2}=1$ if business 0 otherwise, $\mathrm{D}_{3}=1$ if employed, 0 otherwise)

\section{Data Analysis and Interpretation}

Socio-Economic Summary of Sample Households

Table 1:- Basic characteristics of sample households

\begin{tabular}{|c|c|c|c|c|c|c|c|c|c|c|c|c|c|c|}
\hline \multirow[t]{2}{*}{$\begin{array}{l}\text { Sample } \\
\text { Woreda }\end{array}$} & \multicolumn{2}{|c|}{$\begin{array}{c}\text { Wealth } \\
\text { Category }\end{array}$} & \multicolumn{2}{|c|}{$\begin{array}{c}\text { Sex of } \\
\text { HH head }\end{array}$} & \multicolumn{3}{|c|}{ Marital status } & \multicolumn{3}{|c|}{ Age } & \multicolumn{4}{|c|}{ Years of Education } \\
\hline & Rich & Poor & $\mathrm{M}$ & $\mathrm{F}$ & Married & Single & widowed & $20-40$ & $41-60$ & $60-80$ & 0 & $1-5$ & $6-8$ & $9-12$ \\
\hline Guraferda & 20 & 45 & 57 & 8 & 56 & 5 & 4 & 26 & 32 & 7 & 41 & 18 & 5 & 1 \\
\hline Sheko & 20 & 30 & 38 & 12 & 45 & 0 & 5 & 20 & 25 & 5 & 36 & 9 & 3 & 2 \\
\hline Meinit Goldiya & 20 & 25 & 35 & 10 & 42 & 1 & 2 & 18 & 21 & 6 & 27 & 10 & 8 & 2 \\
\hline Meinit Shaha & 16 & 24 & 32 & 8 & 35 & 1 & 4 & 16 & 20 & 4 & 28 & 6 & 4 & 2 \\
\hline Sub total & 76 & 124 & 162 & 38 & 178 & 7 & 15 & 80 & 98 & 22 & 132 & 16 & 20 & 7 \\
\hline Total & \multicolumn{2}{|c|}{200} & \multicolumn{2}{|c|}{200} & \multicolumn{3}{|c|}{200} & \multicolumn{3}{|c|}{200} & \multicolumn{4}{|c|}{200} \\
\hline
\end{tabular}

Source: Own computation, 2014

The study was conducted based on a total of 200 sample households from four Woredas. The gender distribution of household heads shows that $81 \%$ are males and the remaining $19 \%$ are females. From the total sampled households, $62 \%$ are poor households and $38 \%$ are wealthy households. Results on years of education attained by the respondents' shows that $66 \%$ of the sampled households have no formal education, $21.5 \%$ have primary education, $9 \%$ have junior secondary education and the remaining $3.5 \%$ of the respondents have high school education level. Regarding the age distribution of the households, $40 \%$ are in the age between 20 and 40 year, $49 \%$ are between 41 and 60 , and the remaining $11 \%$ are found above 60 years old.

\section{Forest Area Coverage}

Table 2:-Forest area coverage in hectares

\begin{tabular}{|l|l|c|c|c|c|c|c|c|}
\hline$\#$ & Woreda & $\begin{array}{c}\text { Land Area } \\
\text { (hectar) }\end{array}$ & $\begin{array}{c}\text { Natural } \\
\text { Forest }\end{array}$ & $\begin{array}{c}\text { Private } \\
\text { forest }\end{array}$ & $\begin{array}{c}\text { Community } \\
\text { forest }\end{array}$ & $\begin{array}{c}\text { Government } \\
\text { forest }\end{array}$ & $\begin{array}{c}\text { Total } \\
\text { forest }\end{array}$ & $\begin{array}{c}\text { Coverage } \\
(\%)\end{array}$ \\
\hline 1 & N. Bench & 92,165 & 18,101 & 4,105 & 10 & 9 & 22,225 & 24.11 \\
\hline 2 & S. Bench & 117,888 & 16,415 & 3,740 & - & - & 20,155 & 17.09 \\
\hline 3 & Sheko & 48,089 & 27,160 & 225 & - & 45 & 27,430 & 57.04 \\
\hline 4 & Guraferda & 228,281 & 126,332 & 208 & - & 60 & 126,600 & 55.46 \\
\hline 5 & Shewa Bench & 46,257 & 8,053 & 90 & 7 & - & 8,150 & 17.62 \\
\hline 6 & M.Goldiya & 165,700 & 62,288 & 3 & - & - & 62,291 & 37.59 \\
\hline
\end{tabular}




\begin{tabular}{|l|l|c|c|c|c|c|c|c|}
\hline 7 & M. Shaha & 277,096 & 158,402 & 3,528 & 2 & - & 161,932 & 58.44 \\
\hline 8 & Bero & 391,160 & 118,007 & 223 & - & - & 148,230 & 37.19 \\
\hline 9 & Surma & 392,299 & 315,843 & - & - & - & 315,843 & 80.51 \\
\hline 10 & Maji & 171,804 & 199290 & 1140 & - & - & 31549 & 18.36 \\
\hline 11 & Mizan-Aman & 1920 & - & 320 & 19 & 54 & 393 & 20.46 \\
\hline Sub total & $\mathbf{1 , 7 6 0 , 8 5 5}$ & $\mathbf{8 2 0 , 6 0 1}$ & $\mathbf{1 2 , 4 4 2}$ & $\mathbf{3 8}$ & $\mathbf{1 6 8}$ & $\mathbf{8 3 3 , 2 4 9}$ & \\
\cline { 1 - 5 } Percentage & & $\mathbf{4 6 . 6 0 \%}$ & $\mathbf{0 . 7 1 \%}$ & $\mathbf{0 . 0 1 \%}$ & $\mathbf{0 . 0 2 \%}$ & $\mathbf{4 7 . 3 2 \%}$ & $\mathbf{4 7 . 3 2 \%}$ \\
\hline
\end{tabular}

Source: Bench Maji zone rural development office, forest resource department, 2014

The result shows that around $47.32 \%$ of the total area of the zone is covered with forest resources. From this amount, most of the coverage $(46.60 \%)$ is natural forest. The remaining $0.71 \%$ is privately owned, $0.02 \%$ is government owned and $0.01 \%$ is a community forest.

\section{Livelihood Strategies of Households}

In the study area, households' combined a variety of livelihood strategies. Among them agriculture is the primary livelihood activity through crop and livestock production. The other main source of income includes extraction of forest products, wage labour, own small businesses, pension, salary and rent income.

Figure 1:-Livelihood strategies of sample households

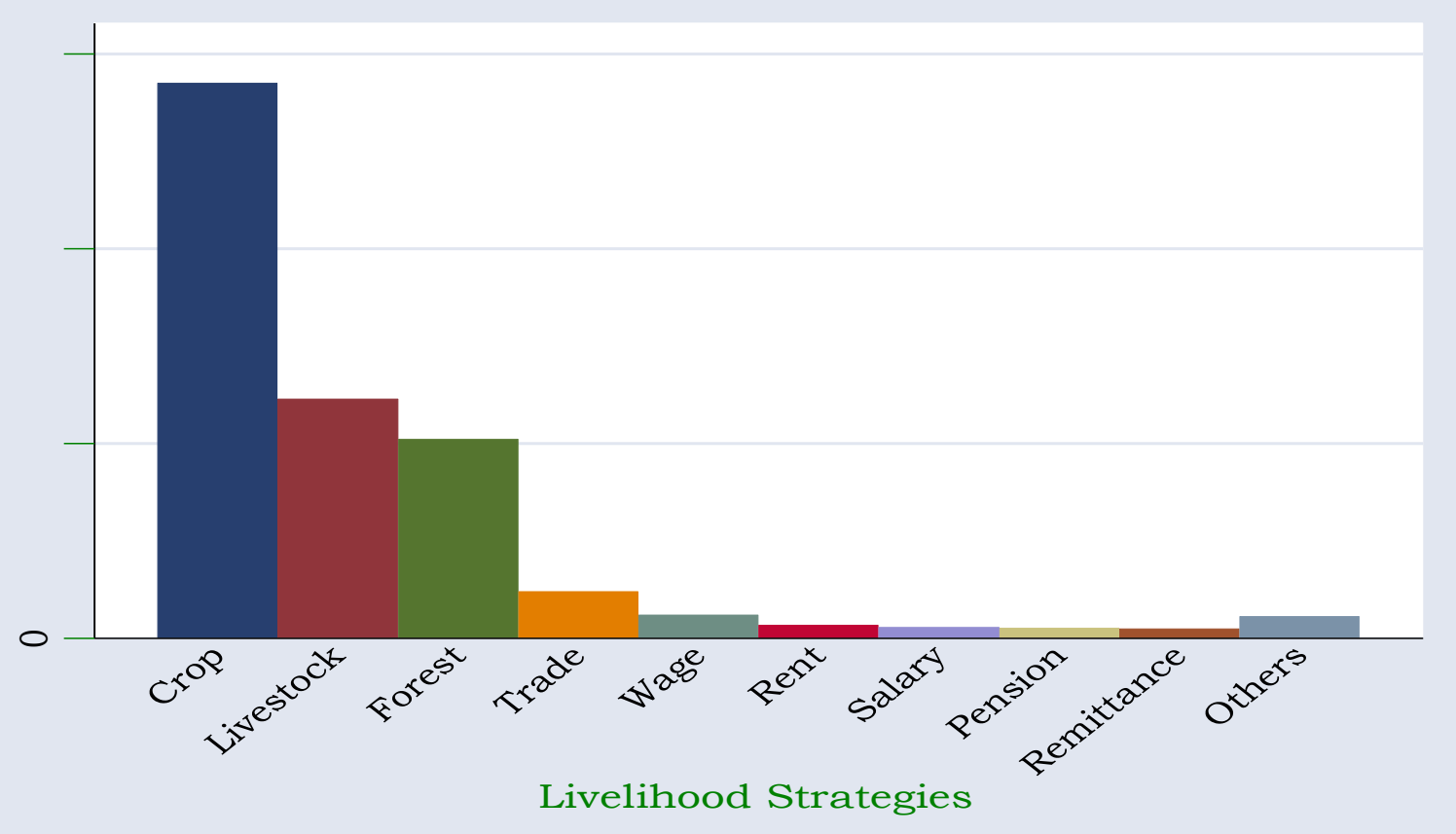

Source: Own computation, 2014

The result shows that agriculture (farm crop and livestock production) takes the largest income share which accounts around $57.9 \%$ of the total households' income. Next to agriculture, selling forest products constitute an important part of the household income portfolio contributing 33\% of total income of the household followed by small trade activities which accounts $3.8 \%$. Other livelihood diversification includes wage labour (1.6\%), income from renting out of land and other equipment $(0.8 \%)$, Salary $(0.5 \%)$, Pension $(0.3 \%)$, Remittance $(0.6 \%)$ and other income sources $(1.5 \%)$ accounts the total income of the households.

\section{Agriculture:-}

The primary source of livelihood in the study area is agriculture through livestock and crop production. In addition to agriculture a significant number of households participated also in off-farm activities like sale of forest products, grass, and traditional handcrafts. Women are also participated in different livelihood activities like cultivating fruits 
and vegetables selling cooked foods and other homemade activities. But the result of this study shows that the livelihood of the households based on this agriculture is vulnerable and at risk. That is, agriculture in the study area is largely dependent on natural rain while drought is common in this area. In addition, Fruits \& vegetables are perishable and there is a critical shortage of market access for these agricultural products.

The data shows that the main type of crops for households' livelihood income includes Maize (81.25\%), rice (74.85\%), Godere (65.3\%) and Enset (53.55\%). In addition, a significant portion of households obtained livelihood income from wheat $(33.5 \%)$, barley $(16 \%)$, potato $(15.85 \%)$, bean $(3.06 \%)$, and other crop types $(21.1 \%)$. However, in the study year many households said that income from crop production is decreasing because of crop failures, bad weather condition and price fluctuation which lowered the mean contribution of crops to household's income.

In addition, the result of this survey shows that a large portion of households generate their livelihood income through different livestock production. Around $78.5 \%$ of the households obtained livelihood income from chicken production, $68 \%$ of the households from sheep, $40.25 \%$ of sample households from cows, and $37.5 \%$ of the households from bulls. Other source of livelihood income includes donkeys for $7.85 \%$ of sample HHs, horses (for $4.5 \%$ ), goats (for 20\%) and other animals (for $8.75 \%$ ). Also the result of this study shows that there is no significant difference in source of income in the four sample areas.

\section{Forest resource income:-}

Forest income is the second most important source of income in the study area. Around 98.2\% of sample households generated their livelihood income from the use of different forest products.

Table 3:-Proportion of sample households using forest products

\begin{tabular}{|r|l|c|c|c|c|c|}
\hline \multirow{2}{*}{ S.N Forest product type } & \multicolumn{3}{|c|}{ Proportion of HHs (\%) } & \multicolumn{2}{c|}{$\begin{array}{c}\text { Overall } \\
\text { (mean) }\end{array}$} \\
\cline { 3 - 7 } & & Guraferda & Sheko & M. Goldiya & M. Shaha & 26.25 \\
\hline 1 & Bamboo & 34.2 & 28 & 24.2 & 18.6 & 48.6 \\
\hline 2 & Wild Vegetable & 64.3 & 78.9 & 58.2 & 90.7 & 88.9 \\
\hline 3 & Fruits & 97.1 & 83.3 & 83.3 & 96.7 & 97.1 \\
\hline 4 & Charcoal & 98.6 & 100 & 93.1 & 98 & 98.75 \\
\hline 5 & Firewood & 100 & 97 & 100 & 60.2 & 69.25 \\
\hline 6 & Fodder for livestock & 76 & 72 & 68.8 & 82 & 87.5 \\
\hline 7 & Timber for construction & 92 & 84 & 92 & 52.1 & 64.45 \\
\hline 8 & Coffee production & 75.2 & 62.5 & 68 & 22.4 & 27.75 \\
\hline 9 & Others forest types & 34.2 & 36.4 & 18 & & 2 \\
\hline
\end{tabular}

Source: Own computation, 2014

The result shows that most of sample households (98.75\%) obtained firewood from the natural forest which is found around them. Charcoal is the second most important forest product for huge portion of the households $(97.1 \%$ of the households) though it is more important to the lower income households relatively. The respondents indicated that charcoal burning and fuel wood selling are sources of daily income for the poor especially during bad times. Other huge portion of the households' uses a verity of different forest products which includes fruits $(88.9 \%)$, timber for construction $(87.5 \%)$, fodder for animals $(69.25)$, coffee production $(64.45 \%)$, wild vegetables $(62.5 \%)$, bamboo $(26.25 \%)$ and other types of forest products $(27.75 \%)$ of the households.

The result from the discussion with sample households indicates that a very little emphasis was given for the cultural, traditional and environmental value of forest resources. Even awareness creation programs on forest resource utilization and conservations by different governmental and non-governmental organization are limited in the study area. Furthermore, the study revealed that there are hindering problems in the utilization of forest resources in the study area including poor marketing and inefficient utilization technique.

The discussion result with target groups shows that in the study area many forest areas have been lost recently. This is because of the higher population pressure and expansion of the agricultural area, and also due to the expansion of commercial coffee plantations by investors. In addition, the remaining natural forest is highly disturbed and highly threatened by illegal timber and charcoal production. 


\section{Other livelihood income sources:-}

Wage labour is another most important means of obtaining income in times of food shortage for landless and land shortage households. A significant amount of households got income through this daily labour activities including mud making, assisting in the construction of houses and other duties. In addition, employment in coffee processing activities is also another source of getting daily wage.

In addition, rural households in the study area are actively engaged in small trading activities like selling fruits and root crops, second hand clothes, butter, honey, different kind of animals, and other items. The result of this study shows that many households in the study area also obtained a significant amount of their livelihood means through different activities like handicraft, pension, remittance from abroad, renting their land and formal employment.

\section{Forest Resource Dependency of Household Characteristics:-}

The forest dependence level of rural households was calculated using the relative forest income as a share of total household income accounts derived from consumption and sale of forest resources. So, the rural households in the study area are dependent on forest for various products and services. The level of dependence (the ratio of forest income from the total livelihood income) is $33 \%$ in in the study area on average.

The relationship between socio-economic characters of the respondents with forest resources use is addressed by using a linear regression model which shows forest income regressed as a function of different socio-economic characters (factors that affect the level of forest dependency) of the respondents such as distance, age, education level, family size, sex, wealth level, and occupation. The multiple linear regression model is estimated using ordinary least square estimation technique (OLS) after the data is checked for different econometric tests. The presence of autocorrelation is checked using Durbin Watson d test and the result shows the data is free from this problem. Also, the white heteroscedasticity test shows that all the variables are free from heteroscedasticity problem. In addition, multicollinearity problem is checked using variance inflation factor. The STATA result is presented as follows;

reg incomff distance age education family sex wealth $\mathrm{d} 1 \mathrm{~d} 2$

Number of obs $=200$

$\mathrm{F}(8,192)=3.42$

Prob $>\mathrm{F} \quad=0.0011$

R-squared $\quad=0.8264$

Adj R-squared = 0.7894

\begin{tabular}{|c|c|c|c|c|c|}
\hline incomff | & Coef. & Std. Err. & $\mathrm{P}>|\mathrm{t}|$ & \multicolumn{2}{|c|}{ [95\% Conf. Interval] } \\
\hline distance | & $-.57928 *$ & 0.1237 & 0.044 & 239.9139 & 335.0725 \\
\hline age & .28304 & .32651 & 0.104 & -6.504994 & 69.07107 \\
\hline education & $-258.1496 *$ & 109.7451 & 0.016 & 169.1513 & 352.8521 \\
\hline family & $.2365^{*}$ & .0785 & 0.020 & 103.6503 & 179.1774 \\
\hline $\operatorname{sex}$ & $-170.3624 *$ & 55.6681 & 0.032 & -1471.952 & -68.77331 \\
\hline wealth | & $-213.544^{*}$ & 101.7447 & 0.000 & 588.7352 & 1838.353 \\
\hline $\mathrm{d} 1$ & $92.21425^{*}$ & 38.5222 & 0.034 & 557.2409 & 772.8124 \\
\hline $\mathrm{d} 2$ & $74.6596 *$ & 29.5485 & 0.005 & 360.1031 & 847.422 \\
\hline _cons & 683.9193 & 676.1054 & 0.313 & -649.7629 & 2017.602 \\
\hline
\end{tabular}

*significant at $5 \%$ level of significant

The regression result shows that all included explanatory variables are significant at 5\% level of significance except age of the household. It shows that forest income is negatively related with distance, education, sex of being male, and wealth level. On the other hand age, family size, agricultural production and business activities are positively related to forest income. The result of this study reveals that distance of the household home from the forest resource has a negative impact on the dependency of forest resources. Thus, as the distance between home and forest area increased by one kilometer, income from sale of forest products decreased by 0.579 . 
Age of the household is insignificant at 5\% level of significance which shows that age is not an important determinant of the household dependence on forest resource. Education level has a negative impact on forest dependence of an individual. That is, forest income of non-educated household is greater than educated one by 258.15 birr which shows that as households become educated, they will be less dependent on forest resources as a means of livelihood income.

As family size increases, households become more dependent on forest resources as a means of generating livelihood income. This study has further shown that gender of household head is a significant determinant of households depending on forest resources. It shows that female headed households are engaged more in selling forest products than male headed households. On average, female headed households generate income of 513.55 from forest products than male headed households for their livelihood activities.

Further the study reveals that wealth of household is the main determinant of being dependent on forest products. Poor households are very dependent on income from forest products as a substantial livelihood income source than their wealthy counterparts. Poor households generate 470.37 more livelihood income from forest products than wealth households keeping other variables constant.

In addition, households engaged in agricultural and business activities are more dependent on forest products than those who are engaged on formal and informal employment. Households who engaged on agriculture gathered 776.12 more income from forest products relative to those who employed. Also, household who engaged on trade activities earn 758.56 more income from forest than households who are employed.

\section{Conclusion and Recommendation:-}

\section{Conclusion:-}

The aim of this study was to investigate the contribution of forest resources on sustainable rural livelihoods in Bench Maji zone. To understand the present situation on forest resource and rural livelihood, a total of 200 sample households are taken from four woredas (Guraferda, Sheko, Menit Shaha and Menit Goldiya). In the study area, rural households' used diversified livelihood strategies. The study result showed that all sampled research woredas have agriculture as their main source of livelihood income through crop production and livestock which accounts $57.8 \%$ of the total income of the household livelihood income even though this agriculture income is vulnerable and at risk because of its dependency on natural rain.

The second largest source of livelihood income is in the study area is natural forest income which accounts $33 \%$ of the total livelihood income. Around $98.2 \%$ of sample households generated their livelihood income from the use of different forest products like bamboo, charcoal, firewood, wild vegetables and fruits and timber for construction. Among these, firewood is the most important types of forest product for around $98.75 \%$ of sampled households. Charcoal burning is the second most important forest product for large portion households in the study area (97.1\% of the households) though it is more important to the lower income households relatively. Other huge portion of sample households uses a verity of different forest products which includes fruits, timber for construction, fodder for animals, coffee production, wild vegetables, bamboo and other types of forest products.

The result of this study also indicated that a very little emphasis was given for the cultural, traditional and environmental value of forest resources. Even awareness creation programs on forest resource utilization and conservations by different governmental and non-governmental organization are limited in the study area. Present forest management strategies seems forests resources as common pool resources which results lack of participation the rural households in forest conservation practices. Rural households in the study area also use other diversified sources of livelihood strategies in addition to agriculture and forest incomes. These diversified strategies include own business/trade, daily labour income, formal and informal employment, and other livelihood activities which are statistically significant. Livelihood strategies like transfer payment, salary income, and pension income have a positive impact on livelihood of the rural household even though the coefficients are weak and insignificant. In analyzing the dependency of different socio-economic characteristics of a rural households on forest resource use, there is a large difference among these characteristics. That is, within the community some households are more forest dependent than others due to age, distance, education level, sex, wealth and occupation. In the study, big differences towards the importance of location to the forest area were observed. That is, rural households living near to the forest area collects more than households who are distant from the forest boundary. 
Regarding age of the household, the result shows that age households are not as such important variable on dependency of forest resources since the coefficient is statistically insignificant even though it is positive implies that aged households are largely dependent on forest use than younger one. The study also found a major difference within the educational level. That is, education level has a negative impact on the dependency of a household on forest resources. As households become educated, they will be less dependent on forest resources as a means of livelihood income. The regression result also showed that as family size increases, households become more dependent on forest resources as a means of generating livelihood income. In addition, gender of household head is a significant determinant of households depending on forest resources. It shows that female headed households are engaged more in selling forest products than male headed households.

Further the study showed that wealth of household is the main determinant of being dependent on forest products. Poor households are very dependent on income from forest products as a substantial livelihood income source than their wealthy counterparts. And households engaged in agricultural and business activities are more dependent on forest products than those who are engaged on formal and informal employment.

\section{Recommendations:-}

The findings of this study have some important implications for policymakers, local government bodies, and other interested agents regarding the contribution of forest resources to the rural household livelihood. As far as natural forest resources have an important contribution in the rural livelihood means, issues on forest resource and rural livelihood should not be ignored in policy decisions and other interventions. Consequently, steps to efficiently use and conserve forest resources should be undertaken by different bodies as one of the ways of improving rural households livelihood means. So, based on the finding of this study, the following recommendations are forwarded.

$>$ In addition to the forest resource use, other income generation activities should be incorporated to promote diversified livelihood strategies and to ensure sustainable livelihood of the local household by reducing dependency on forests.

$>$ To avoid deforestation and inefficient utilization of forest resources, participatory forest management should be effectively practiced. That is, the local community should be organized themselves and actively participated in decision making regarding the management of forest resources. Thus, an appropriate balance is needed to maximize benefits from the forest resources as well as conserving them for sustainable use.

$>$ In addition, to reduce forest degradation and to utilize them sustainably awareness on cultural, traditional and environmental importance of forest resources should be created through training, education, community discussion and other means. Government can improve inefficient utilization of forest resources by improving rural road network and marketing system. In addition government will do well to put in place strategies that will help to check the destructive use of forest resources in the study area.

$>$ In the study area, most low income rural households generated livelihood income through the sale of charcoal and firewood to the urban community which are the most causes of deforestation. So, other means of income generating activities should be encouraged for the rural household and alternative means of energy should be provided to the rural people in order to reduce the pressure on the natural forest.

$>$ The study showed that wealth level of the individual is one of the major determinants of forest dependency of households. So, one of the most important policy implications of this study is that intervention seeking to reduce poverty in a forest dependent rural economy through rising income of the rural poor by other means.

$>$ In the study area still other socio-economic characteristics like sex, family size, distance between household home and forest area, and occupation have a significant burden on the natural forest. So, policy measure to this end should include non-timber forest product utilization, effective forest conservation management system, and economic empowerment of women, reducing poverty through providing subsidy and credit for the poor, implementing participatory forest management and creating awareness.

$>$ Since less educated rural households are largely dependent on forest resources, it is necessary to increase the education level of households through providing training and enhancing formal and formal education in the rural area.

\section{Acknowledgement:-}

We acknowledge Institute of Research and Community Development Support Directorate of Mizan Tepi University for the financial support to conduct this research. We also would like to express our thanks to all the sampled households for their time and kind cooperation in providing necessary information for the study. 


\section{Reference:-}

1. Bekele Taye. (2001). The potential of Bonga Forest for certification: Paper for National stakeholder workshop on forest certification. Addis Ababa, Ethiopia.

2. Bench Maji zone trade and industry office. (2012): http://www.benchimaji-tradeindustry. gov.et/ retrieved on $15 / 11 / 2016$

3. CSA. (2008). The 2007 Population and Housing Census of Ethiopia report. February 2008. Addis Ababa, Ethiopia.

4. Dahal, M.R. 2006. Benefit-Cost Analysis of Community Forest and its Distributional Impact on Rural Poor. Economic Journal of Nepal Vol. 29 No 2.

5. FAO, 2003. State of the world`s forests. Rome. pp 151.

6. Mamo, G., Sjaastad, E. \& Vedeld, 2007. Economic dependence on forest resources: A case from Dendi district, Ethiopia. Forest Policy and Economics, 9, 916-927 modified on 18 March 2013 at 11:06. Retrieved on $15 / 11 / 2013$

7. NTFP, 2004. Non Timber Forest Products Research and Development Project in South-west Ethiopia. Wageningen

8. Oksanen, T. \& Mersmann, C. (2003). Forests in poverty reduction strategies. Assessment of PRSP processes in Sub-Saharan Africa. pp. 121-155.

9. Paumgarter, F. \& Shackleton, C.M. 2011. Wealth differentiation in household use and trade in non-timber production in South Africa. Ecological Economics, Vol 68 Issue 12, pp. 2950-2959.

10. Scoones, I. 1998. Sustainable rural livelihoods: a framework for analysis. Brighton: Institute of Development Studies.

11. SDPRP (2002): Sustainable Development and Poverty Reduction Program. Addis Ababa, Ethiopia.

12. Shackleton and Shackleton, 2006. The importance of non-timber forest products in rural livelihood security and as safety nets: a review of evidence from South Africa. South Asian Journal of Science, pp 658-664.

13. United Nation, 2011. Forests for people fact sheet: international year of forest.

14. WBISPP (2005). A national strategy plan for the biomass sector. Addis Ababa, Ethiopia. 